\title{
Artur Hazelius, Nordiska museet och ansvaret för kulturarvet
}

\author{
Magdalena HilLströM*
}

Title: Artur Hazelius, Nordiska museet and responsibility for cultural heritage. Abstract: The thesis traces and analyses important changes in cultural heritage and museum politics during the nineteenth century. It tells two overlapping narratives. One is about the creation and expansion of Nordiska museet, and about the museum founder, Artur Hazelius. The other concerns the indecisive construction of meaning and organisational forms for state responsibility for the cultural heritage. The nineteenth century is commonly described as a time when cultural heritage became a concern of the state. This thesis instead sheds light on the uncertainties involved in the construction of national cultural heritage politics. It emphasises the crucial role played by voluntary organisations. It observes the significance of histories and of counter-histories in the controversies obout the ownership of the cultural heritage and responsibility for maintaining it. The thesis also focuses on the emergence of a museum profession and its implications for the development of Nordiska museet and for museum politics in general.

Key words: Sweden, nineteenth century, antiquarianism, heritage politics, heritage preservation, Svenska Fornminnesföreningen, museum, history of museums, Nordiska museet, Artur Hazelius.

\section{PROLOG}

Museer tycker om jubileer. I Sverige gäller det kanske särskilt Nordiska museet och Skansen. Listan över dyrbara minnesfester och högtidspublikationer kan göras lång. Sentida exempel är den påkostade och rikt illustrerade boken Nordiska museet 125 ar (1998), och uppmärksammandet av den nuvarande museibyggnadens 100-års jubileum 2007.' I samband med det senare gjorde man en utställning under rubriken "Megasamlaren - om museernas samlande". Historien har sett många mega- samlare och till dem hörde Artur Hazelius, grundläggaren av Nordiska museet (1873) och Skansen (1891).

Nordiska museets nuvarande monumentalbyggnad på Djurgården i Stockholm öppnades för allmänheten 1907. De utställningar som då skapats för skådelystna, bildningsivrare och vetenskapsmän fick Artur Hazelius (1833-1901) själv aldrig uppleva, än mindre bestämma över. Sex år tidigare, medan byggnaden ännu stod halvfärdig och man förberedde för Skansens årliga vårfest, hade han hastigt ryckts bort. 
Artur Hazelius död 1901 medförde en museipolitisk scenförändring av sällan skådat slag. I nästan tre decennier hade han styrt över Nordiska museet med obändig vilja, envishet och kraft - för att plötsligt vara borta. 1900talets första år blev en orostid för museet. Problemen hopade sig. Starka konflikter bröt ut kring deras lämpligaste lösningar. Vem skulle bli ny styresman för museet? Enligt vilka principer skulle Nordiska museets stora samlingar sorteras, ordnas och ställas ut i den nya museibyggnaden? Vilken roll skulle museets traditioner spela för den framtida verksamheten? Vad ingick $\mathrm{i}$ en museimans arbetsuppgifter och vilka kompetenskrav skulle man ställa?

Artur Hazelius museiverksamhet hade under åren varit utsatta för misstänksam kritik och museipolitiska fiender saknades inte, riksantikvarien Bror-Emil Hildebrand (1806-1884) och hans efterträdare Hans Hildebrand (1842-1913) hörde till dessa. När museigrundaren var död fick gamla konflikter nytt spelrum. Men det var inte i första hand gamla meningsskiljaktigheter som satte sin prägel på de museipolitiska dragkamper som följde i spåren av Artur Hazelius bortgång. Det var nya och de hade nya bärare.

I slutet av 1800-talet började det kulturhistoriska museiväsendet $\mathrm{i}$ allmänhet att professionaliseras. Kring sekelskiftet 1900 var professionens strävanden efter modernisering och kontroll över museiväsendet framträdande. De museiideologiska och museipolitiska konsekvenser var stora, inte minst som framväxten av en yrkesmedveten grupp av akademiskt utbildade museimän medförde mer eller mindre angreppslystna försök till gränsdragningar mellan en "omodern" och en "modern" museikultur. Den framväxande museiprofessionen förstod som sin uppgift att renodla och förädla museerna. Det handlade om att skapa museiinstitutioner jämbördiga med andra forskningsinstitutioner och bildningsinrättningar. Ledorden var föremål, ordning och vetenskap. Yrkeskompetensens kärnpunkt definierades som föremålskunskap. Samlingarna och den systematiska ordningen av föremål inom ämnes- och specialområden stod i centrum. En rad olika museiformer, utställningssätt, samlingstyper och museiideologier började framställas som otidsenliga och främmande för det moderna museets idé. Gränserna mot dessa museikulturens avarter - de illegitima släktingarna - fastställdes och bevakades av inflytelserika museiideologiska aktörer.

I Stockholm fanns vid sekelskiftet 1900 en grupp av yngre och professionellt självmedvetna museimän. De bildade en kamratkrets som kallades "Fackföreningen". Flera av dem arbetade vid Nordiska museet. Museimännen i "Fackföreningen" ansåg att den äldre generationens museimän i allmänhet och Artur Hazelius i synnerhet representerade ett "omodernt" museiväsende och att Nordiska museet och Skansen inte uppfyllde kraven på "moderna" och vetenskapligt syftande museiinstitutioner. De fruktade att verksamheten vid Nordiska museet och Skansen skulle fortsätta som under Hazelius tid och höll före att förnyelse var viktigare än tradition när man skulle besluta om museets framtid. Om man höll fast vid Artur Hazelius otidsenliga museisyn skulle Nordiska museet stelna till ett minnesmonument över grundläggaren och en museikultur som tiden hade lämnat bakom sig.

1800-talets museikultur med sin brokiga mångfald var ett brännande problem för "Fackföreningens" medlemmar. En överordnad styggelse var, ansåg man, sammanblandningen av museer som vetenskapligt upplysande föremålsarkiv och som publikfriande och illusionsskapande teater. Nordiska museet 


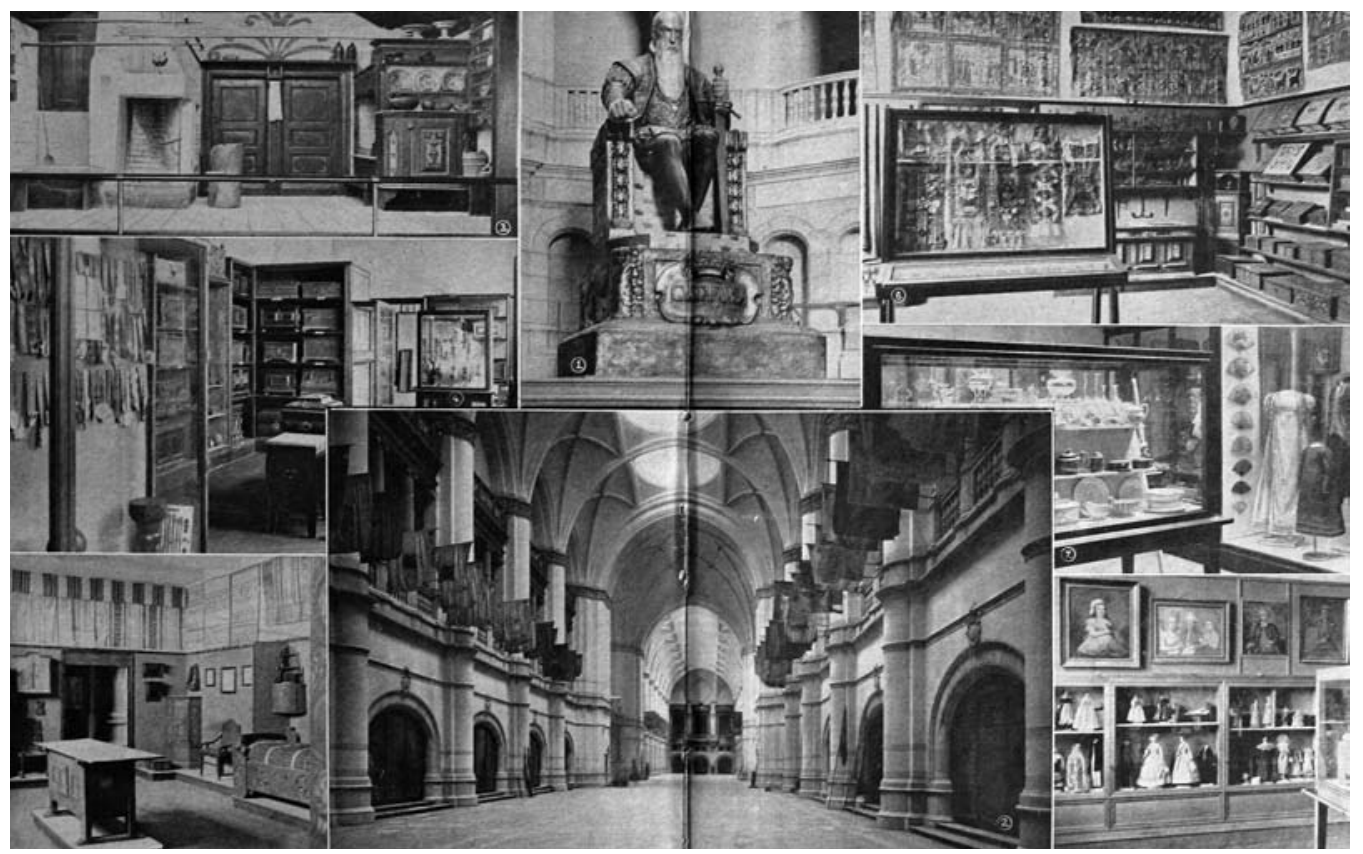

"Några glimatar från Nordiska museet", i: Hvar 8 Dag, no. 37, årg. 8 (1907). Foto: Gustag Lindh.

var en sådan problematisk hybrid men ett ännu större problem var Skansen. Det var osäkert om Skansen över huvud var ett museum. Ett "museum", så skulle saken fattas, var en byggnad eller institution som rymde systematiskt ordnade samlingar (senare under 1900talet började man betrakta byggnaderna på Skansen som museiföremål). Friluftsmuseet framstod för de unga museimännen som en obehaglig påminnelse om den "omoderna" museikulturens publikfriande former och de skickligheter hos de anställda som dessa krävde. Yrkeskompetensen hos en "modern" museiman bestod inte av att arrangera festliga historiska maskeradtåg, att ta hand om björnungar och renar eller att ringa i kyrkklockorna. I synnerhet fick man inte, som brukligt var på Skansen, använda museiföremål som rekvisita eller underhållande färdmedel. Museiföremål brukades inte. De bevarades i syfte att främja forskningen inom skilda områden.

I min avhandling Ansvaret för kulturarvet: Studier $i$ det kulturhistoriska museiväsendets formering med särskild inriktning på Nordiska museets etablering 1872-1919 tecknar jag huvuddragen av professionaliseringens konsekvenser för det kulturhistoriska museiväsendet. Framväxten av en självmedveten museiprofession utgör ett spår i vad jag har kallat avhandlingens "stora" och "lilla" berättelse. Den lilla berättelsen handlar om Nordiska museet och om Artur Hazelius som museigrundare och museipolitiker. Den börjar omkring 1870. Den stora berättelsen förankrar det kulturhistoriska museiväsendets framväxt och formering i en 
mera vidsträckt och kronologiskt utsträckt historie- och museipolitisk kontext. Den tar sin början i 1800-talets första decennier. I avhandlingen är båda berättelsernas kronologiska slutpunkt 1919. Då togs de första verkningsfulla stegen mot en statlig museipolitik och Nordiska museet etablerades som ett kulturhistoriskt centralmuseum. Avhandlingen är ett bidrag till den svenska museihistorien, men den är inte i första hand en institutionshistoria. Den är inte heller en biografi över Artur Hazelius. I stället har jag strävat efter att ge en bred och mångfacetterad bild av historie- och museipolitiken under 1800-talets och 1900-talets första decennier.

\section{OMVANDLINGSSAMHÄLLET}

Den stora berättelsen handlar om osäkerhet i flera dimensioner. Historikern Torkel Jansson har i boken Adertonhundratalets associationer: Forskning och problem kring ett sprängfyllt tomrum eller sammanslutningsprinciper och föreningsformer mellan två samhällsformationer, c:a 1800-1870 karaktäriserat perioden mellan enhetsstatens upplösning och den kapitalistiska statens genombrott kring 1870 som omvandlingssamhället. ${ }^{2}$ Omvandlingssamhället innesluter övergången från feodala till kapitalistiska produktionsförhållanden, ståndssamhällets gradvisa omvandling till partistaten och omvandlingen från skråsamhällets privilegieorganisation till "det konkurrensbaserade intresseorganisationssamhället". Det som gör Janssons studie intressant i relation till historiebevarandet under 1800-talet är hans belysning av hur associationsväsendet - det frivilliga föreningsbildandet - vinner insteg under en period som präglades av en grundläggande osäkerhet om riktningen för samhällsutvecklingen. Innebörderna av begrepp som staten och samhället, det offentliga och det privata, det allmänna och det enskilda var stadda i omvandling. Man var osäker på hur samhället skulle organiseras, vilken roll staten skulle spela och vad ett medborgarsamhälle innebar. Det gamla samhällets grundpelare, kungamakten, ståndskorporationerna och kyrkan, försvagades successivt. Ståndssamhället föll sönder, nya samhällsklasser uppstod, kyrkan förlorade stegvis sin makt. Det äldre samhällssystemet var i upplösning och man kunde inte på förhand veta vad som skulle träda i dess ställe.

Den osäkerhet som präglade omvandlingssamhället öppnade i samspel men en liberal frihetsideologi upp för ett större medborgerligt engagemang och nya idéer om samhällets organisering lanserades. Associationerna, den frivilliga sammanslutningen som form för allmänintressets organisering, växte fram. Associationsväsendet äger sin motsvarighet i Jürgen Habermas teori om framväxten av en "borgerlig offentlighet". ${ }^{3}$ Associationsväsendet, menar Jansson sammanfattningsvis, framträdde som en form av samhällsorganisation under den gradvisa övergången från feodalstaten till den kapitalistiska staten. Då övergången mellan dessa två samhällssystem var en långsam process uppstod ett samhällsorganisatoriskt "tomrum". Studiens undertitel "ett sprängfyllt tomrum" syftar på förhållandet att tomrummet var sprängfyllt av samhällsalternativ, av associationsbildningar.

\section{HISTORIEBEVARANDE I OMVANDLINGSSAM- HÄLLET}

Många musei- och kulturarvshistoriker har beskrivit 1800-talet som en period av stark statlig mobilisering på det musei- och historiepolitiska fältet. I Sverige har bilden av staten 
som en kraftfull aktör dessutom kunnat målas fram med 1600-talets historiepolitik som imponerande fond. Statens engagemang i historiebevarandet har karaktäriserats som uråldrigt och rentav hävdvunnet. Detta perspektiv har spelat en avgörande roll för föreställningen om en symbios mellan staten och kulturarvet, en symbios som manifesterade sig i hägnet av stormaktspolitik och göticism under 1600-talet och som en kraftfull yttring av nationalism, historicism och romantiska idéströmningar i den framväxande moderna staten under 1800-talet. ${ }^{4} \mathrm{I}$ avhandlingen visar jag att den gängse bilden av en symbios mellan staten och kulturarvet under 1800-talet är starkt förenklad.

Det är otvetydigt att 1800-talet bevittnade ett nytt slags intresse för historien och historiebevarandet men man bör inte förlora ur sikte att uppmärksamheten på det förflutna uppträder samtidigt som omvandlingssamhället inträder och gradvis, så småningom helt genomgripande, förändrar historie- och museipolitikens förutsättningar. Det var i själva verket osäkert vad historiebevarandet syftade till, vilken mening som historiebevarandet hade i en liberal stat, vad allmänintresset omfattade, vad historien skulle handla om och på vilka legitimitetsgrunder bevarandet av minnena vilade. Det var osäkert vem som ägde ansvaret för historiebevarandet, vilken roll staten skulle spela, vem som ägde fornminnena och i vilken samhällssfär vården av dem hörde hemma: i den privata eller i den offentliga. Omvandlingssamhället medförde, kort sagt, omvandlingar som i grunden förändrade förutsättningarna för och meningen med historiebevarandet. Lika lite som 1800-talsmänniskan kunde förutse samhällsutvecklingen på lång sikt, kunde hon förutse vad historiebevarandets roll i denna skulle bli. Brytningen "mellan en av staten reglerad och kontrollerad samhällsmodell och en frihetlig och medborgerligt centrerad", för att citera historikern Lars Båtefalk, förändrade historiens politiska, sociala och kulturella rum. ${ }^{5}$

\section{ANSVARET FÖR KULTURARVET}

Ett genomgående tema i avhandlingen rör frågan om ansvaret för kulturarvet. Den tidsperiod som avhandlingen omfattar kännetecknades av bestående spänningar och osäkerheter om formen, räckvidden och fördelningen av detta ansvarstagande. Frågan om historiebevarandets ställning i samhället var kopplad till den övergripande osäkerheten om vilken samhällsordning som rådde och borde råda. Under den konfliktfyllda och ostadiga gången från kungastaten och ståndssamhället till den demokratiska staten lånade frågorna kring fornminnen och kulturhistoriska samlingar glöd och storhet från den större kampen om samhällsordningen. Etableringen av nationalismen som överideologi innebar att talet om fosterländskt historiebevarande kunde hållas på en retorisk anspråksfull nivå. Den politiska praktiken - det statliga organisatoriska och ekonomiska engagemanget i historiebevarandet - förblev begränsat under hela undersökningsperioden. Statens ovilja att ta ett vidgat (och kostsamt) ansvar för historiebevarande var en bidragande anledning till framgången för Artur Hazelius museiprojekt.

Ett uttryck för den sammanfallande osäkerheten om historiebevarandet och samhällsordningen var den vacklande betydelsen av en mängd närstående ord som "offentlig", "allmän”, "politisk", "publik", "statlig", "samhällelig", "social", "nationell", "fosterländsk", "officiell", "myndighets-", "riks-", "kunglig", "civil", "borgerlig", "medborgerlig" och "folklig". 
110 Att historiebevarandet på ett "allmänt" plan var en samhällsangelägenhet av "allmän", "nationell", "samhällelig" och "fosterländsk" betydelse kunde erkännas av i stort sett alla aktörer under det långa 1800-talet. De flesta ansåg att det var en "allmän" eller "offentlig" angelägenhet $\mathrm{i}$ betydelsen att den hörde hemma i den medborgerliga offentligheten, även i riksdagens politiska offentlighet. En del hävdade att frågan var "allmän" också i betydelsen att "staten" ägde ett övergripande ansvar för historiebevarande. Några menade till och med att "staten" var ägare av fornminnena, att de var "allmän" eller "offentlig" egendom, att frågorna därför var "riksangelägenheter" och tillhörde ett "officiellt myndighetsfält". Andra bestred detta och ville lägga det "allmänna" ansvaret på det civila samhället, på "allmännyttiga" stiftelser, enskilda associationer och ansvarstagade enskilda medborgare och mecenater som verkade i det "allmännas" och i "allmänhetens" tjänst. De ansåg att kulturarvet tillhörde "nationen", "folket" och "fosterlandet", men det betydde inte att "staten" kunde förfoga över det, eller att ansvaret för bevarandet av det förflutnas lämningar var en myndighetsuppgift. Gränslinjerna för statligt, kungligt, civilsamhälleligt och enskilt ansvar för historien är i rörelse under hela perioden och med dessa rör sig också betydelserna av alla de ord som används för att artikulera arten av samhällelighet, offentlighet eller allmänhet i detta ansvarstagande. ${ }^{6}$

\section{SVENSKA FORNMINNESFÖRENINGEN OCH BRONSERNA}

En tydlig lillustration till de många osäkerheter som den stora berättelsen om ansvaret för kulturarvet försöker frilägga är bildandet av Svenska Fornminnesföreningen 1869. Föreningen kom att spela en viktig roll för tillkom-

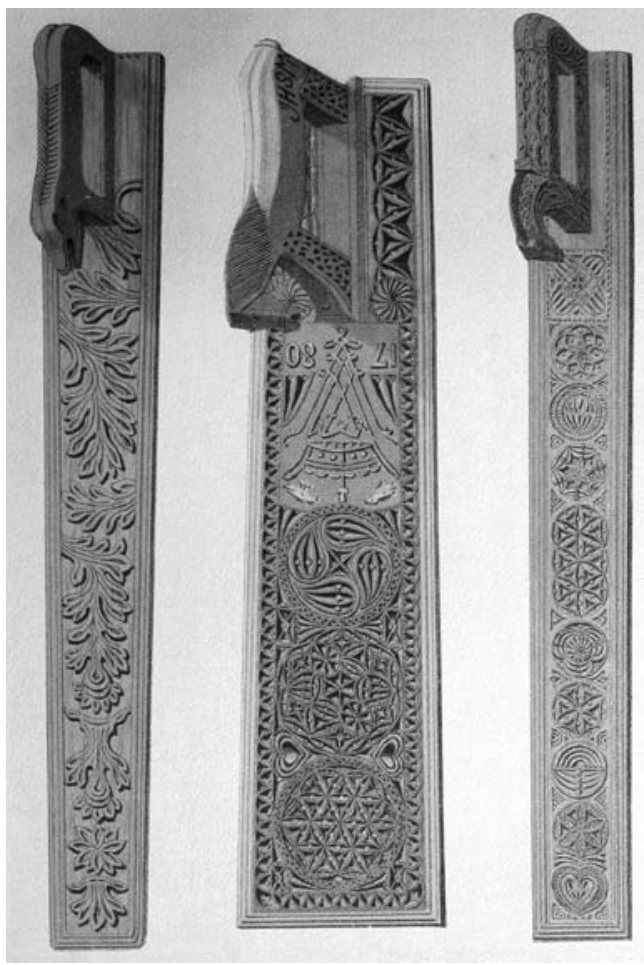

"Kafvelbräden frän södra och mellersta Sverige", i: Artur Hazelius, Minnen frän Nordiska museet: Afbildningar afföremål i museet jämte àtföljande text (Stockholm, 1885). Foto: Gustag Lindh.

sten av en ny fornminnesförordning 1873 , i vilken fornföremål av brons undandrogs hembudsplikten. De laddade och konfliktfyllda meningsutbyten som föregick den nya förordningen har kallats bronsfejden.

Mot bakgrund av Svenska Fornminnesföreningens engagemang för en förnyad lagstiftning har den i historieskrivningen kommit att betraktas som en proteströrelse. Föreningens tillkomst har tolkats som ett utspel direkt riktat mot historiebevarandets officiella företrädare i allmänhet och den dåvarande riksanti- 
kvarien Bror Emil Hildebrand och dennes bundsförvanter i Kungliga Vitterhets historie och antikvitets akademien synnerhet. Flera forskare har intresserat sig för föreningen just som en oppositionssammanslutning. De har utgått från kravet på en förändring av fornminnesförordningen i sin karaktäristik av föreningens målsättningar och menar att bronsfejden utkristalliserade centrala konfliktlinjer i 1870-talets historie- och museipolitik: självlärda fornminnesentusiaster/professionella, amatörism/vetenskap, enskilt/statligt, privat/offentligt, landsort/huvudstad etcetera. ${ }^{7}$

I avhandling visar jag att bilden av två rivaliserande och i huvudsak homogena konstellationer är starkt förenklad. Tvärtom speglar de diskussioner som fördes inom föreningen tidens osäkerheter när det gällde svaren på frågorna om vem som hade ansvaret för det förflutnas lämningar, hur skyddet skulle organiseras, hur forskningen skulle regleras, vad historiebevarandet syftade till, hur gränserna skulle dras mellan det privata och det offentliga. Svenska Fornminnesföreningen samlade aktörer med olikartade syften. Innehållet i den fria och frivilliga fornforskningen respektive den officiella (som den kallades) gavs olika mening, liksom relationen mellan dem. Svenska Fornminnesföreningen företrädde inte något enhetligt historie- och museipolitiskt program, lika lite som Vitterhetsakademien eller riksantikvarien gjorde det. I de principiellt centrala frågorna om ansvar för och ägande av historiska minnesmärken och föremål, om fördelning mellan regionalt och centralt museiansvar, om vetenskapliga kontra andra motiv för bevarande, om den övergripande fördelningen av historiepolitiska roller mellan stat och civilsamhälle rådde inte någon enighet. Svenska fornminnesföreningen framträder snarare som en arena för artikulation av den genomgripan- de osäkerheten om de rätta svaren på dessa frågor än som en tydlig historie- och museipolitisk alternativrörelse med klara handlingslinjer och motiv. Föreningen kom, oavsiktligt, att bidra med större tydlighet åt denna villrådighet och mångformighet än med ett alternativ till den rådande ordningen, $i$ all synnerhet som den rådande ordningen var påfallande oordnad.

\section{ARTUR HAZELIUS - NYKOMLINGEN}

1873 steg Artur Hazelius (1833-1901) in på museiarenan och stannade där. Då öppnades Skandinavisk-etnografiska samlingen (namnet ändrades till Nordiska museet 1880) på Drottninggatan i centrala Stockholm. Hazelius hade då namn av "språkman", men hade genom sitt engagemang i den då aktuella nystavningsfrågan blivit skandaliserad och marginaliserad bland tongivande språkforskare. Med öppnandet av (den ännu lilla) Skandinavisk-etnografiska samlingen lämnade Hazelius sin plats i offentligheten som socialt komprometterad neograf och tog i stället plats i den som samlare och museiman. Som skäl för sitt museiinitiativ angav han att den snabbt bortdöende gamla allmogekulturen saknade en officiell museirepresentant och att det var i avsikt att fylla denna lucka i det offentliga museiväsendet som han hade bildat ett museum. Det var, hävdade Hazelius, den enskildes plikt att göra något för bildandet av ett svenskt etnografiskt museum.

När Artur Hazelius i början av 1870-talet trädde fram som samlare och museigrundare stod han ännu i periferin av det historie- och museipolitiska spelrummet. Det skulle visa sig att tillkomsten av Nordiska museet efterhand gav återverkningar på hela det musei- och historiepolitiska området. Nordiska museet blev 
112 både en drivkraft och en stridsplats för det framväxande kulturhistoriska museiväsendet. Den "lilla berättelsen" i avhandlingen tecknar dragen av museets gång från en liten privatsamling - som ägdes av Artur Hazelius men hade bildats med "allmänhetens" hjälp - över tillkomsten av en ny organisation 1880, då museet sades vara "hela folkets egendom", vidare över de stora konflikter om museets mening och syfte som inträffade efter grundläggarens död 1901 och - slutligen - till museets frivilliga inordning $\mathrm{i}$ en statlig museipolitik, officiellt kodifierad år 1919.

\section{MÅNGTYDIGHET OCH OSÄKERHET}

Det som samtiden kom att uppfatta som karaktäristiskt för Nordiska museet var den till synes tygellösa expansionen av museiverksamheten. Samlingarna växte med en häpnadsväckande hastighet $\mathrm{i}$ riktningar som ingen hade kunnat förutse. Nya utställningar, avdelningar och annex kom till och föremålen vagabonderade mellan museets så småningom många lokaler på Drottninggatan. Bilden av museiverksamheten som i första hand föränderlig framträdde i dagstidningar, veckomagasin och månadsjournaler redan från Skandinavisk-etnografiska samlingens begynnelseår. Den välavgränsade målsättningen att bilda en samling av allmogeföremål, som Artur Hazelius först deklarerade, hade redan ett par år senare förvandlats till ett expansivt, mångformigt och svårtytt kulturhistoriskt storföretag. Det blev efter hand uppenbart att det ständigt ökande antalet avdelningar inte kunde betraktas som mer eller mindre tillfälligt tillkomna sidovägar till ett huvudspår.

Redan i begynnelsen av Artur Hazelius museiverksamhet hade osäkerheter uppstått. Nog kunde många se att ingen av de befintliga statssamlingarna ägnade allmogeföremålen något större intresse och att Hazelius initiativ i denna mening fyllde en lucka. Men vad var meningen med att denna lucka fylldes? Vad syftade Skandinavisk-etnografiska samlingen till? I stort sett allt som skrevs om Skandinavisk-etnografiska samlingen innehöll olikartade påståenden om museets betydelse, mening och mål. En förklarade att Skandinavisk-etnografiska samlingen var ett konstindustriellt museum ämnat att bidra till utvecklingen av en konkurrenskraftig konstindustri, en annan att museet var ett unikt och viktigt tillskott till kunskaperna om svenskheten. En tredje framhöll att museet stod i medborgerlighetens tjänst: målet var att överbrygga klassklyftorna, utradera klassosämja och gamla ståndsfördomar. En fjärde påstod att museet framför allt bidrog med material till den framväxande etnografiska vetenskapen. Artur Hazelius själv bejakade alla dessa förslag till bestämningar av museets motiv och legitimitet.

En annan oklarhet gällde museets art av offentlighet. Hela svenska folket uppmanades att bidra till samlingens växt, men vem ägde egentligen museet? Det fanns ingen formaliserad organisation, inga stadgar, ingen styrelse, ingen revisor, inga medlemsavgifter men var och en kunde hjälpa till att utveckla museet och förkovra samlingarna. Alla var välkomna att lämna gåvor av föremål till samlingarna eller på andra sätt bli dess välgörare och härigenom associera sig med museet. Museets iscensattes som en enskild inrättning med allmänna syften och som "allmänt", det vill säga en gemensam samhällsangelägenhet. Men var Skandinavisk-etnografiska samlingen egentligen Hazelius privata egendom? Kunde Hazelius tänkas sälja samlingarna vid ett senare tillfälle och behålla köpesumman för egen räkning? Vad var det egentligen all- 
mänheten bidrog till och för vem? Tvivlen minskade inte när Artur Hazelius började göra gällande att han betraktade alla föremål som skänkts till samlingarna såsom statens egendom. Om gåvor som skänktes till Skandinavisk-etnografiska samlingen betraktades som tillhöriga staten, vem var i så fall ägare av de andra föremålen i museet? Ur rättslig synvinkel var innebörden av påståendet dessutom oklar.

Med samlingarnas hastiga tillväxt uppförstorades oklarheternas mått. Oklarheterna gällde inte bara frågan om vad Nordiska museet var för slags museum, utan också vad det var avsett att bli. Vilka var egentligen Hazelius ambitioner och långsiktiga mål? Vad var det för slags museum som han avsåg att skapa och skapade? Hur skulle den oavbrutna utvidgningen av samlingsområdena förstås i förhållande till den första visionen om ett museum för allmogens minnen och till de målsättningar som tidigare gjorts gällande? På vilket sätt bildade samlingarnas så småningom alltmer heterogena delar en meningsfull helhet?

Samlingarnas växt i förbindelse med deras uppenbara brokighet bidrog till en annan osäkerhet. Vad för slags museiman var Hazelius? Var han en "riktig" museiman"? En misstanke spred sig att Hazelius i själva verket samlade på allt och att det var hans omättliga begär efter mera - om än i förvillande museimannaförklädnad - som närmast föranledde museiverksamhetens utvidgning.

Det uppstod också en osäkerhet om legitimiteten för att överskrida det ämnesområde, den skandinaviska etnografin, som Hazelius först hade avsett att bilda en samling för. Artur Hazelius hade gjort gällande att det samlingsområde som han avsåg att ägna sig åt saknade offentliga företrädare. Det hade försummats av statens museer. Att bilda Skandi- navisk-etnografiska samlingen var därför en allmän angelägenhet på ett område som saknade offentliga företrädare. När samlandet expanderade långt utöver de slags antikviteter som klassificerades som allmogens minnen, när det grep in på samlings- och museiområden som redan representerades av andra offentliga samlingar, kunde museiverksamheten inte längre motiveras med att den fyllde ett tomrum.

I början av 1880-talet började Artur Hazelius planerna för en museibyggnad åt Nordiska museet. År 1891 offentliggjordes Isak Gustaf Clasons ritningar för det nya Nordiska museet. Clasons förslag bar vittnesbörd om en storslagen museidröm. Den tillämnade byggnaden var enorm. Museet bestod i Clasons förslag av en främre länga med en huvudentré och en bakre, kortare och bredare, hallbyggnad. Längorna förenades i mitten av en hall och på sidorna genom två tvärlängor. I hörnen reste sig mäktiga rundtorn (endast en byggnad i det stora komplexet kom att resas, det nuvarande Nordiska museet). ${ }^{8}$ Förslaget till den nya byggnaden visade på ambitionen att skapa ett museum som skulle omfatta, med tidens språkbruk, hela odlingshistorien från äldsta tid intill nutid. Museet skulle innehålla alla de slags föremål som rymdes i samtidens antikvitetsbegrepp - och mera därtill. Det var ett museum som blandade en rad vid tiden etablerade musei- och samlargenrer. Det var också ett museum, som genom sin tänkta storlek och i kraft av visionen att täcka hela det antikvariska och kulturhistoriska området, kunde göra andra överflödiga. Det planerade museets gigantiska storlek bekräftade vad somliga museiaktörer befarade, nämligen att Hazelius och hans medhjälpare och finansiärer hyste planer på att i grunden omstöpa huvudstadens museiväsende. 
NORDISKA MUSEET - EN GÅVA TILL FOLKET?

Frågan om museets art av offentlighet fick förnyad aktualitet när Artur Hazelius år 1880 författade ett överlåtelsebrev där Nordiska museet ställdes som en självständig stiftelse (då under benämningen "anstalt") under ledning av en nämnd. Äganderätten till samlingarna, inventarier och fonder inräknade övergick till stiftelsen under det att Hazelius personligen tog på sig ansvaret för museets skulder. Artur Hazelius gjorde gällande att han med denna manöver skänkt Nordiska museet till det svenska folket.'

Överlåtelsen år 1880 tydliggjorde att Hazelius som privatperson inte reste några anspråk på att äga museet. Hans idealitet kunde härigenom inte längre betvivlas. I form av en stiftelse för allmänna ändamål hade museet fått en organisation som allmänheten kunde känna igen. Museets status som allmän inrättning var inte längre lika hårt knuten till Hazelius person, sociala status och karisma. Samtidigt kom någon skarp gräns mellan Hazelius som privatperson och Nordiska museet som stiftelse inte att upprättas, trots återkommande försök från styrelsens sida att helt skilja museiverksamheten från Hazelius privatekonomi. Osäkerheten om museets art av offentlighet kvarstod.

Vid tiden för museets omorganisation 1880 erbjöds allmänheten att teckna sig som medlemmar i en förening: Samfundet för Nordiska museets främjande. Sedan museiverksamhetens början hade allmänhetens bidrag spelat en avgörande roll. Bildandet av samfundet organiserade museets allmänintresse, både konkret och bildligt. Genom att allmänheten kunde göras till medlemmar i en förening förtydligades museets plats $\mathrm{i}$ en civilsamhällelig offentlighet. Hazelius utfästelser om att Nord- iska museet var hela folkets egendom tycktes bekräftade. Men bildandet av Samfundet för Nordiska museets främjande lämnade också ett bidrag till osäkerheten om museets offentlighet, trots att det syftade till att demonstrera Nordiska museet just som en civilsamhällelig och allmän angelägenhet. Det hade visserligen blivit möjligt för enskilda att på ett tydligare sätt associera sig med museet men Samfundet hade inget med museets förvaltning eller ledning att skaffa. Styrelsen för Nordiska museet valde sig själv, och det var egentligen bara den och styresmannen själv som hade insyn i och kontroll över museiverksamheten. Det kunde därför inte riktigt klarläggas på vilket sätt som Nordiska museet var svenska folkets egendom, i synnerhet som äganderätten till samlingarna otvetydigt övergått till en stiftelse.

\section{DEN LILLA BERÄTTELSEN I LJUSET AV DEN STORA BERÄTTELSEN}

På ett allmänt plan speglar Nordiska museets mångtydighet den samtida historie- och museipolitikens öppenhet och osäkerhet. På 1870-talet var många av de sentida bestämningarna av det kulturhistoriska museiområdet och museipraktikerna ännu inte gjorda. Ovissheten om vilket ansvar det allmänna skulle ha på det kulturhistoriska museiområdet var ett centralt inslag i denna osäkerhet, liksom frågan om det var statliga eller civilsamhälleliga former som detta allmänna ansvar skulle ta. Osäkerheten bildade grunden för en allieringsstrategi där Hazelius kunde visa fram olika bilder av museets funktion på olika arenor och för olika grupper. Osäkerheten om museets betydelse och Hazelius intentioner var inte någon hämsko. Den var förutsättningen för museiverksamhetens expansion och en mångfacetterad alliansbildning. Haze- 


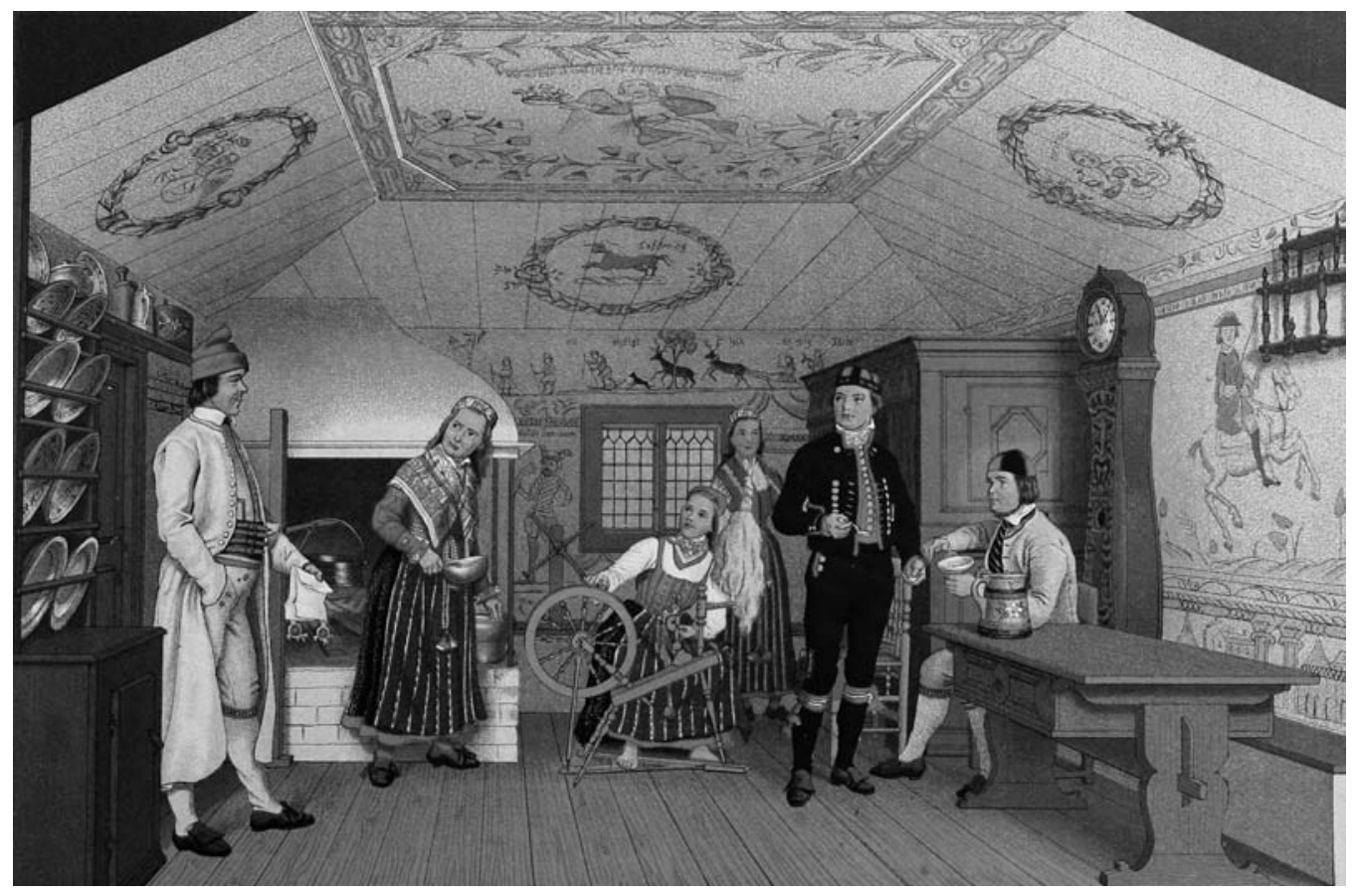

"Stuga i Delsbo socken i Helsingland" i: Artur Hazelius, Minnen frän Nordiska museet. Afbildningar afföremål i museet jämte ätföljande text (Stockholm, 1885). Foto: Gustag Lindh.

lius undvek att tydliggöra sina planer för att kunna skapa breda allianser för sin museiverksamhet och för att möjliggöra samlingarnas framgångsrika expansion genom gåvor från allmänheten. Otydligheten i museiprojektets mening och mål gjorde det möjligt att identifiera det med en rad olika slags betydelser och strävanden och lämnade öppet för olika tillskrivningar. Genom att avstå från att utstaka andra än ytterst allmänna gränser för museiverksamheten, och genom att undvika att bestämma samlingarnas innehåll och omfång, skapade Hazelius utrymme för att välkomna alla som ville skänka gåvor till museet. Ingen behövde riskera att bli avvisad som gåvogivare och medskapare av museet.
Osäkerheten om Nordiska museets art av offentlighet speglar på motsvarande sätt "omvandlingssamhällets" dynamiska men stegvisa samhällsförändringsprocess och de för tiden karaktäristiska glidande betydelserna av ord som "allmän", "enskild" och "offentlig." Men det är också högst rimligt att se Hazelius själv som bärare av tidens osäkerheter om historiebevarandets innehåll, mening och organisering. Han, liksom andra, sökte olika lösningar på historiebevarandets problem och legitimitet.

När man i Artur Hazelius samtid framhöll de makalösa framgångarna för Nordiska museet avsåg man i första hand samlingarnas remarkabla tillväxt och omfånget av allmänhe- 
116 tens frivilliga bidrag. Samlingarnas storlek och värde bar vittnesbörd om Hazelius storhet som museiman och gjorde honom till en museibildare som andra aktörer på huvudstadens museiscen inte kunde ignorera. Drömmen om och planerna på en ny byggnad för museet vittnade om monumentala och storslagna planer på ett kulturhistoriskt riksmuseum och ambitionen att befästa Nordiska museet som huvudansvarstagare för de nationella (eller rentav nordeuropeiska) kulturhistoriska samlingarna. Frågan om huruvida Hazelius museiverksamhet innebar en otillbörlig expansion över samlingsområden som redan företräddes av andra offentliga museer berör frågan om ansvarstagande, fördelning av ansvarstagande och de framväxande kraven på en statlig museipolitik. Artur Hazelius främste motståndare hette Hans Hildebrand. Han var riksantikvarie under åren 1897-1907) och chef för Statens historiska museum. Hildebrand verkade för att utveckla Statens historiska museum till ett kulturhistoriskt riksmuseum. I vägen för dessa planers lyckosamma genomförande stod Artur Hazelius. Han hade obefogat klampat in på statssamlingens revir, ansåg Hildebrand. En möjlig väg till kontroll över Hazelius vittfamnade verksamhet var att staten löste in Nordiska museet, något som Hildebrand verkade för. Så blev det inte. Det kraftfulla museipolitiska initiativ som han hoppats att staten skulle ta gentemot Nordiska museet uteblev. I stället övergick museet till en stiftelse och Hildebrands nederlag var ett faktum.

År 1919 sågs de första ansatserna till en statlig museipolitik. Då fastställde Kungl. Maj:t gränserna mellan ansvarsområdena för Statens historiska museum, konstavdelningen vid Nationalmuseum, Livrustkammaren och Nordiska museet. Nordiska museets inord- ning i den statliga museipolitiken var frivillig, men museets styrelse välkomnade den officiella ansvarsregleringen och var mycket belåten med nyordningen. Museet, så fattade man saken, hade blivit ett centralmuseum. Det hade tilldelats ett särskilt kulturhistoriskt uppdrag och inordnats under statens övergripande museiansvar.

Beslutet att reglera Nordiska museets och nämnda statssamlingars ansvarsområden markerade något nytt i det kulturhistoriska museiväsendets framväxt: staten tog på sig uppgiften att ordna det offentliga museiväsendet. Det ljumma intresse som staten tidigare hade visat de kulturhistoriska museerna hade varit gynnsamt för Nordiska museets utveckling och expansion. När museet 1880 övergick till en stiftelse lyckades grundläggaren Artur Hazelius säkerställa sitt spelutrymme gentemot statssamlingarna. År 1919 (då Hazelius sedan länge var död) välkomnade Nordiska museets styrelse tillpassningen till de statliga museerna och inordningen i statsförvaltningen. Samma tillpassning och inordning hade Hazelius under sina år som museets ägare - och efter 1880 som styresman - envist, uppfinningsrikt och med framgång motsatt sig.

Att hävda museets status som offentlig institution var viktigt för legitimiteten och trovärdigheten, inte minst gentemot beskyddare och finansiärer. Detta betydde i första hand anspråk på att vara en allmännyttig, ideellt och fosterländskt syftande inrättning av nationell betydelse. Samlingarna framhölls som folkets och nationens egendom och museigärningen som Hazelius personliga kallelse i fosterlandets tjänst. Offentlig status var också betydelsefullt för att hävda museet som en legitim lärd inrättning i vetenskapens tjänst. Samtidigt ansträngde sig Hazelius av flera skäl att skydda sin skapelse från att förknippas mer di- 
rekt och formellt med staten. Den civilsamhälleliga grunden för verksamheten var central. Den gav ett manöverutrymme gentemot de statliga museerna, i första hand i förhållande till Statens historiska museum. Hazelius vidstäckta vän- och släktskapsrelationer och presskontakter - med det Jürgen Habermas kallat "den borgerliga offentligheten" - utgjorde den sociala grundvalen för museiverksamhetens framgång.

Med 1919-års gränsreglering hade ett statligt museipolitiskt ansvarstagande - om än begränsat - etablerats och arbetsfördelningen mellan de inblandade museerna hade givits form och innehåll.

Verksamheten vid de kulturhistoriska museerna hade bekräftats som en angelägenhet för staten. För den framväxande museiprofessionen, som sökte status och legitimitet, var beslutet en stor framgång, inte minst som man såg möjligheter till det gamla och brokiga museiväsendets ordnande, specialisering och systematisering. 1919-års gränsreglering gav hopp om Nordiska museets framgångsrika modernisering.

\section{HISTORIENS CIVILISERING}

I avhandlingen är frågan om arten och räckvidden av samhällsansvaret för kulturarvet kulturhistorien under 1800-talet den övergripande. Den rör gränserna för det statliga ansvaret, både gentemot den enskilde medborgarens ansvar inom äganderättens och näringsfrihetens ram, och gentemot ett civilsamhälleligt och associationsbaserat ansvarstagande. Frågan om samhällsansvaret för kulturarvet rör dels relationen mellan äldre kungastatliga styrformer och den civila statens institutioner och dels mellan ett äldre kungligt och aristokratiskt patronats- och mecenatsansvar och civilsamhällets nya mecenater. Avhandlingen visar att det under 1800-talet växte fram en rad blandformer mellan kungliga, civilstatliga och civilsamhälleliga ansvarsstrukturer.

De många osäkerheterna kring det samhälleliga ansvarstagandets art och omfång, organisering och motiv, som stod i blickfältet för historiebevarandets aktörer, kom efter hand och med historiebevarandets och museiväsendets professionalisering ytterligare att kompliceras.

Professionaliseringen innebar, bland mycket annat, en förskjutning av uppmärksamheten mot vem och vilka som hade den rätta kompetensen att ansvara för kulturarvet.

I avhandlingen har jag försökt att belysa dessa invecklade förhållanden genom att uppmärksamma avvägningarna mellan statligt, civilsamhälleligt och enskilt ansvar för fornminnena. Jag har också försökt belysa dem genom att fokusera på arten av Nordiska museets offentlighet. Det är inte lätt att i efterhand få en klar bild. Det var svårt för de historiska aktörerna själva att enas om vilka ansvarsförhållanden som faktiskt rådde eller borde råda. $\mathrm{Hu}$ vudanledningen till oklarheterna är att den mindre frågan om samhällets ansvar för kulturarvet var sammanvävd med den större osäkerheten om samhällsordningens utformning och färdriktning.

Avhandlingens tidsperiod, "det långa 1800talet”, rymmer en mångfacetterad rörelse på de historie- och museipolitiska arenorna som man kan kalla civilisering. Tematiskt innebar denna rörelse att den officiella historien kungamaktens, krigens och inrikespolitikens - utvidgades till det civila samhällets, folkets, allmogens och de borgerliga skiktens historia. Civiliseringen var också del av en sekulariseringsprocess. I dess kölvatten tillskrevs natio- 
118 nen, konsten, vetenskapen och kulturen den helgd som tidigare varit förbehållen kyrkan och i viss mån konungens person. För den civila statens legitimitet blev ansvaret för civilisationsprocessen en viktig del. Folkskolans övertagande av kyrkans folkundervisningsuppgifter är ett av många exempel. Sekulariseringen medförde också historiemedvetandets civilisering. Samhällsorganisatoriskt betydde civiliseringen att civilsamhällets aktörer - rörelser, föreningar, sällskap, stiftelser, enskilda mecenater och kultursträvande idealister - fick spela en allt viktigare roll. Av och till och med olika styrka utmanade de civilsamhälleliga strävandena den officiella historie- och politiska samhällsordningen. En borgerlig offentlighet växte fram i sociala nätverk och press. Den gjorde anspråk på att vara den legitima grunden för samhällsordningen i kungamaktens, stånds- och skråordningens efterföljd. Ur förvaltningssynpunkt medförde civiliseringen att en civil statsmakt fick ett växande ansvar för kungliga och furstliga samlingar och mecenatsuppgifter. Alla dess aspekter av civilisering bäddade för att den civila och nationella kulturhistorien började framträda som det centrala objektet för historie- och museipolitik.

Civiliseringen framträder $\mathrm{i}$ efterhand som en identifierbar utvecklingslinje under det långa 1800-talet. Den pekar mot statens expansion under 1900- talets första decennier. Men, nota bene, 1800-talets människor hade ingen motsvarande bild av en bestämd utvecklingsriktning för samhällsordningen. Övergången från kungastaten till den fullt ut förverkligade demokratiska staten rymde många samhällsorganisatoriska alternativ.

Civilstatens civiliseringsuppgift accentuerades under 1900-talet. Under 1800-talet var den framträdande inom utbildningspolitiken.
Historie- och museipolitiken som statligt politikområde var svagt. Med utgångspunkt i kulturarvsbevarandet framträder i stället de enskilda och civilsamhälleliga initiativen som avgörande. Men, detta är omvandlingssamhället: både civilstatens och civilsamhällets historiebevarande präglades av historiska överlagringar av motiv och museipraktiker. Kungastaten hade inte spelat ut sin kulturarvsbevarande roll. Den representativa offentlighetens motiv överfördes så sakteliga till den civila staten. Övergången från kungastat till civilstat var en långsam process. "Det långa 1800talet" vittnar om flera förskjutningar i motiven för samhälleligt engagemang på det kulturhistoriska området. Det vittnar också om en bestående, ibland motsägelsefull, komplexitet i dessa motiv. En av grunderna för Artur Hazelius framgångar var att han bejakade dem alla.

\section{AVHANDLINGENS PERSPEKTIV}

Ansvaret för kulturarvet innehåller som sagt två berättelser, den stora berättelsen om ansvaret för kulturarvet och den lilla berättelsen om tillkomsten och etableringen av Nordiska museet. De centrala skeendena i den stora och den lilla historien beskrivs $i$ avhandlingen genom tio avgränsade empiriska nedslag. Det inledningsvis omnämnda museipolitiska konflikter som följde efter Artur Hazelius död är ett sådant. Nedslagen motiveras av det förändringsperspektiv, kronologiskt och tematiskt, som organiserar avhandlingen. De avgränsade empiriska nedslagen är detaljrikt återgivna och analyserade, med det är egentligen bara konturerna av den stora och den lilla historien som avhandlingen kan berätta.

Men det är inte bara två historier som berättas. De berättas också ur ett dubbelt per- 
spektiv. Det ena är förändringsperspektivet. Det andra perspektivet är det historiografiska. Ett utmärkande drag för den dubbla historia som avhandlingen berättar är den roll som historieskrivningen har spelat, både för formeringen av det kulturhistoriska museiväsendet och för efterhandsförståelsen av detsamma. Under 1800-talet kom berättelser om den statliga historie- och museipolitikens ursprung i 1600-talet att användas för att legitimera det statliga ansvarstagandet för historiebevarandet. Historien användes som ett argument för att historiebevarandet skulle inordnas i statsförvaltningens myndighetsorganisation. Till bilden av de kontroverser som spelades upp under 1800-talet, kontroverser som gällde ansvaret för, utsträckningen av, meningen med samt kontrollen och tolkningsföreträdet över historiebevarande, hör skapandet av mothistorier. Dessa syftade till att underminera föreställningen om att staten av hävd hade ett särskilt historie- och museipolitiskt ansvar. Ett exempel är Gabriel Djurklous debattskrift Om svensk fornforskning och Kongl. Maj:ts nadiga förordning af den 29 november 1867, utgiven 1872. Djurklous och många andra mothistorier är sedan länge glömda. ${ }^{10}$

I slutet av 1800-talet framträdde en annan ursprungshistoria, Nordiska museets. I likhet med den förra fyllde berättelserna om museiplanernas upprinnelse och utveckling berättigande syften. Genom att lägga historien om Hazelius som museigrundare till rätta försökte man avvärja den kritik mot museet som riktades från skilda håll. Frågetecken upprestes inför motivgrunderna för samlingarnas hastiga expansion i vittfamnande riktningar. Tveksamheter uttrycktes om samlingarnas kvalité och innehåll. Hazelius idealitet ifrågasattes och misstankar om oseriösa insamlingsmetoder väcktes. Det handlade också om att anpas- sa musei- och samlarverksamheten till de framryckande professionella kraven på vetenskaplig och sakliga grund. Historieskrivningens mål var bland annat att göra Nordiska museet likvärdigt med de statliga museerna, att skapa enhetlighet åt och förbindelser mellan de stora heterogena samlingarna, att förtydliga museets samhälleliga betydelse och att säkerställa det ädla i Hazelius intentioner.

Avhandlingen eftersträvar att berätta en empiriskt välgrundad historia om "det långa 1800-talets" historie- och museipolitik, det centrala kulturhistoriska museiväsendets formering och Nordiska museets och Artur Hazelius dynamiska roll i denna. Den vill lyfta fram och tydliggöra historieskrivningens centrala betydelse för att skapa legitimitet åt stridiga historie- och museipolitiska målsättningar och visioner under 1800-talet. Min förhoppning är att kunna öppna upp för en ny historieskrivning, en historieskrivning som sträcker sig bortom etablerade och kanoniserade nationella berättelser om kulturarvet och dess bevarande. Sedd i ljuset av samtidens kulturpolitik fäster Ansvaret för kulturarvet: Studier $i$ det kulturhistoriska museiväsendets formering med särskild inriktning på Nordiska museets etablering 1872-1919 uppmärksamheten på att många av 2000-talets historie- och museipolitiska frågor befann sig på dagordningen redan under 1800-talet. De frågor som då stod på spel står alltjämt på spel: de offentliga museernas uppgifter och ansvar, gränserna för statens ansvarstagande, vad man skall ta ansvar för och under vilka former, vilka som är de behöriga aktörerna och vilka deras kompetenser bör vara, relationen mellan amatörer och professionella, balanseringen av statliga och civilsamhälleliga ansvarstaganden och initiativ, historiebevarandets motivgrunder etcetera. 
I slutet av 1890-talet hade Artur Hazelius berättat för sin son Gunnar Hazelius att han hoppades att denne ville överta chefskapet för Nordiska museet den dag fadern dog eller av åldersskäl var tvungen att dra sig tillbaka. Gunnar Hazelius godtog faderns önskemål, men utgången skulle visa sig tragisk. Gunnar Hazelius blev aldrig utnämnd till styresman och dog i blödande magsår den 26 februari 1905. Det tycktes då som att Artur Hazelius önskan hade kostat hans enda barn livet.

När Artur Hazelius i testamentariska anteckningar förordade Gunnar Hazelius som den lämpligaste att överta museichefskapet framhöll han sonens förtrogenhet med museets traditioner och med faderns planer och vilja för det samma. Några mera självständiga erfarenheter av museiarbetet hade Gunnar Hazelius inte och hans auktoritet kom därför att vila på förmågan att göra faderns vilja och planer gällande. Hans position var förenad med många svårigheter.

Artur Hazelius hade framgångsrikt lyckats hävda sin frihet som museiman. Det var en frihet som inbegrep utrymme att göra det som han själv fann riktigt och önskvärt, frihet från att ägna sig åt tidsödande motiveringar och frihet från hänsynstaganden till vad andra eventuellt ansåg. Gunnar Hazelius position var mycket svagare än faderns. Han stod inför uppgiften att tolka och artikulera innebörderna av den mångtydiga och heterogena museiverksamhet som fadern hade lämnat efter sig. Möjligheterna att söka stöd i skriftliga dokument som hade formulerats av fadern var få. Detta förhållande underströk Gunnar Hazelius roll som uttydare av museets traditioner och faderns intentioner. Hans tolkningar av i vilken riktning Artur Hazelius hade tänkt att

museet skulle utvecklas ifrågasattes. Han var inte heller den ende som gjorde anspråk på att äga kännedom om Artur Hazelius förhoppningar och planer. Dessutom skulle han samtidigt försvara faderns museiideal gentemot gamla och nya kritiker. I Gunnar Hazelius blickfält stod faderns önskan att han skulle föra museets traditioner vidare. Gunnar Hazelius hade ett vaket öga för de många svårigheter som hans roll som traditionsförvaltare medförde och det är uppenbart att hans tilltro till faderns idéer inte alltid var oreserverad. Men det största hindret för att Gunnar Hazelius skulle lyckas i sin strävan var förmodligen tvånget att gå från handling till program. Artur Hazelius hade etablerat ett mångtydigt och mångskiftande museum. Det hade skapat en öppenhet som möjliggjort olika slags tolkningar och växlande alliansbildningar. Osäkerheten om ambitionerna hade bidragit till en tolerans för oklarheten i museiidén. När Gunnar Hazelius inträdde på museiscenen bidrog han till att renodla konfliktmönster i stället för att göra som sin far och oförskräckt jonglera med "principerna”. I kraft av sitt försvar för fadern blev Gunnar Hazelius en förespråkare för museiideal som de professionellt medvetna museimännen ansåg förlegade.

De unga museimännen i "Fackföreningen" hade stora förväntningar på att Nordiska museet skulle överge de gamla museiidealen och framträda som ett modernt och vetenskaplig museum. Men helt maktlös mot dessa sina motståndare var inte Gunnar Hazelius. Ingen, inte ens Hazelius bittraste kritiker, hävdade utåt att troheten mot museets grundare saknade betydelse. Pieteten mot Artur Hazelius museiskapelser var inte ett hänsynstagande i marginalen av andra. Pieteten var en maktfaktor i kraft av den roll som "allmänheten" hade tilldelats som medskapare av Nordiska museet. 
Många av Hazelius bundsförvanter var ännu i livet. Man kunde inte bortse från alla släktingar och vänner. De kretsar av kollektiva mecenatsskap som byggs upp kring museiverksamheten hade fortsatt en viktig ekonomisk betydelse. Den avgörande roll som förtroendet för Artur Hazelius hade spelat från begynnelsen av museiverksamheten kunde inte sidoställas. Sammantaget innebar detta krav på en avläsbar kontinuitet mellan det "gamla" Nordiska museet, Artur Hazelius museum, och det "nya", som reste sig på Lejonslätten. Ingen som var involverade i frågan om hur det "nya" Nordiska museet skulle gestalta sig kunde bortse från ansvaret för Artur Hazelius minne.

\section{Artiklen bygger på afhandlingen: Magdalena} Hillström. Ansvaret för kulturarvet: Studier $i$ det kulturhistoriska museiväsendets formering med särskild inriktning på Nordiska museets etablering 1872-1919. Linköping Studies in Arts and Science No. 363. Tema Kultur och sambälle, Linköpings universitet, Linköping 2006. Avhandlingen kommer inom kort att finnas tillgänglig på Linköping University Electronic Press: http://www.ep.liu.sel.

\section{NOTER}

1. Hans Medelius et al (red.), Nordiska museet under 125 år (1998); Christina Westergren (red.), Brokiga samlingars bostad (2007).

2. Torkel Jansson, Adertonhundratalets associationer: Forskning och problem kring ett sprängfyllt tomrum eller sammanslutningsprinciper och föreningsformer mellan två samhällsformationer c:a 1800-1870 (1985).

3. Jürgen Habermas, Borgerlig offentlighet: Kategorierna "privat" och "offentligt" i det moderna samhället (1984).

4. Se t.ex. Henrik Schück, Kgl. Vitterhets historie och antikvitets akademien: Dess förhistoria och historia, 8 vol. (1932-1944); Sten Lindroth, Svensk idé- och lärdomshistoria: Stormaktstiden (1978); Svante Beckman, "Vad vill staten med kulturarvet?" i: Kulturarvets natur, red. Annika Alzén och Johan Hedrén (1998); Jonas Grundberg, Kulturarvsförvaltningens samhällsuppdrag: En introduktion till kulturarvsförvaltningens teori och praktik (1999); Patrik Hall, Den svenskaste historien: Nationalism i Sverige under sex sekler (2000); Richard Pettersson, Fädernesland och framtidsland: Sigurd Curman och kulturminnesvårdens etablering (2001);

5. Lars Båtefalk, Staten, samhället och superiet: Samhällsorganisationernas principer och organisatorisk praktik kring dryckenskapsproblemet och nykterhetssträvandena i stat, borgerlig offentlighet och associationsväsende c:a 1770-1900 (2000).s. 157.

6. Svenbjörn Kilander, Den nya staten och den gamla: En studie i ideologisk förändring (1991). Kilander analyserar förskjutningar i innebörderna av "privat" och "offentligt" under 1800-talet och det tidiga 1900-talet.

7. Lars Sellberg, Av kärlek till fosterland och folk: Gabriel Djurklou och dialektforskningen (1993); Kerstin Arcadius, Museum på svenska: Länsmuseerna och kulturhistorien (1997); Evert Baudou, Gustaf Hallström: Arkeolog i världskrigens epok (1997); Grundberg (1999); Pettersson (2001); Olof Ljungström, Oscariansk antropologi: Etnografi, förhistoria och rasforskning under sent 1800-tal (2004).

8. Isak Gustaf Clason, Förslag till en byggnad för Nordiska museet (1891).

9. Artur Hazelius, Dr A. Hazelii öfverlåtelsebref af den 18 april 1880 samt Nordiska museets stadgar, 3. uppl. (1890).

10. Nils Gabriel Djurklou, Om svensk fornforskning 
och Kongl. Maj:ts nådiga förordning af den 29 november 1867 (1872).

\section{REFERENCER}

Alzén, Annika \& Johan Hedrén (red.), Kulturarvets natur (Eslöv, 1998).

Arcadius, Kerstin, Museum på svenska: Länsmuseerna och kulturhistorien (Stockholm, 1997).

Baudou, Evert, Gustaf Hallström: Arkeolog i världskrigens epok (Stockholm, 1997).

Beckman, Svante, "Vad vill staten med kulturarvet?" i: Kulturarvets natur, red. Annika Alzén och Johan Hedrén (Eslöv, 1998).

Båtefalk, Lars, Staten, sambället och superiet: Samhällsorganisationernas principer och organisatorisk praktik kring dryckenskapsproblemet och nykterhetssträvandena $i$ stat, borgerlig offentlighet och associationsväsende c:a 1770-1900 (Uppsala, 2000).

Djurklou, Gabriel, Om svensk fornforskning och Kongl. Maj:ts nådiga förordning af den 29 november 1867 (1872).

Grundberg, Jonas, Kulturarvsförvaltningens sambällsuppdrag: En introduktion till kulturarvsförvaltningens teori och praktik (Göteborg, 1999).

Habermas, Jürgen, Borgerlig offentlighet: Kategorierna "privat" och "offentligt" i det moderna sambället (1962), sv. övers. (Lund, 1984).

Hall, Patrik, Den svenskaste historien: Nationalism $i$ Sverige under sex sekler (Stockholm, 2000).

Hazelius, Artur, Dr A. Hazelii öfverlåtelsebref af den 18 april 1880 samt Nordiska museets stadgar, 3 . uppl. (Stockholm, 1890).

Isak Gustaf Clason, Förslag till en byggnad för Nordiska museet (Stockholm, 1891).

Jansson, Torkel, Adertonhundratalets associationer: Forskning och problem kring ett sprängfyllt tomrum eller sammanslutningsprinciper och föreningsformer mellan två sambällsformationer c:a 1800-1870 (Stockholm, 1985).
Kilander, Svenbjörn, Den nya staten och den gamla: En studie i ideologisk förändring (Stockholm, 1991).

Lindroth, Sten, Svensk idé- och lärdomshistoria: Stormaktstiden (Stockholm, 1978).

Ljungström, Olof, Oscariansk antropologi: Etnografi, förhistoria och rasforskning under sent 1800-tal, ny bearb. utg. (Hedemora, 2004).

Medelius, Hans et al (red.), Nordiska museet under 125 ar (Stockholm, 1998).

Pettersson, Richard, Fädernesland och framtidsland: Sigurd Curman och kulturminnesvardens etablering (Umeå, 2001).

Schück, Henrik, Kgl. Vitterhets historie och antikvitets akademien: Dess förhistoria och historia, 8 vol. (Stockholm, 1932-1944).

Sellberg, Lars, Av kärlek till fosterland och folk: Gabriel Djurklou och dialektforskningen (Uppsala, 1993).

Westergren, Christina (red.), Brokiga samlingars bostad, Serie: Fataburen 2007 (Stockholm, 2007).

* Magdalena Hillström (FD) är forskare vid Tema Kultur och sambälle (Tema Q), Linköpings universitet. Hon disputerade år 2006 pa avhandlingen Ansvaret för kulturarvet. Studier i formeringen av det kulturhistoriska museiväsendet $i$ Sverige med särskild inriktning på Nordiska museets etablering 1870 - 1920. Fakultetsopponent var docent Anders Ekström, Avdelningen för teknik-och vetenskapshistoria, Kgl. Tekniska högskolan, Stockholm.

Adresse: Magdalena Hillström (FD) Tema Kultur och sambälle (Tema Q) Linköpings universitet 60174 Norrköping

E-mail: Magdalena.Hillstrom@liu.se 